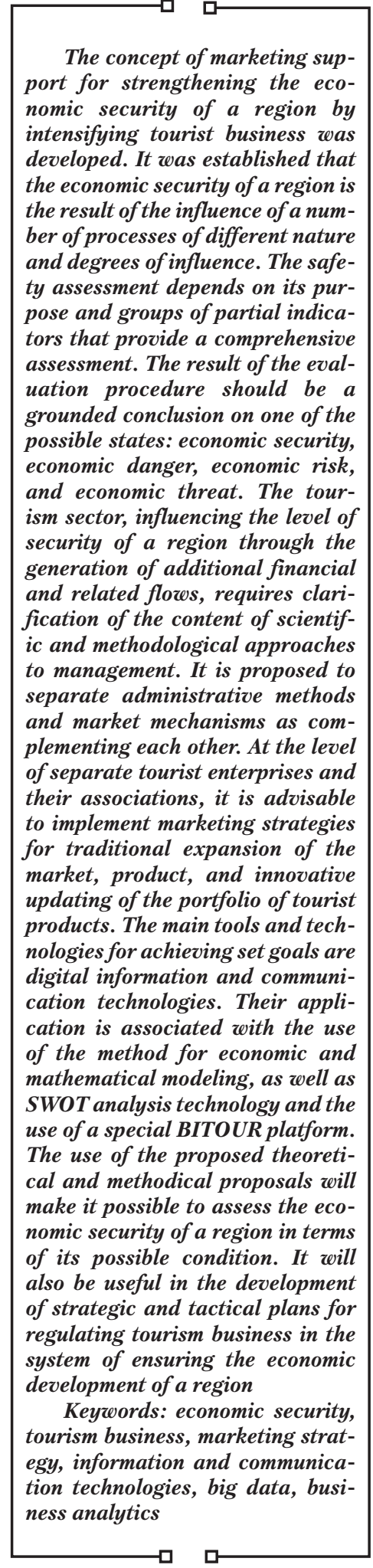

UDC 332.1: 339.13: 338.48

DOI: $10.15587 / 1729-4061.2021 .238397$

\title{
DEVISING SCIENTIFIC AND METHODOLOGICAL TOOLS TO STRENGTHEN THE ECONOMIC SECURITY OF A REGION THROUGH THE IMPROVEMENT OF TECHNOLOGIES FOR MARKETING SUPPORT OF TOURISM
}

\author{
Vadym Ratynsky i \\ Corresponding author \\ $\mathrm{PhD}$, Associate Professor \\ Department of Accounting and Audit* \\ E-mail: ratvadim@gmail.com \\ Natali a Tymosh y \\ $\mathrm{PhD}$, Associate Professor
} Department of Economics and Finance*

Roman Sherstiuk

Doctor of Economic Sciences, Head of Department Department of Innovation Activity and Services Management*

O Ien a $D$ u d k in a

$\mathrm{PhD}$, Associate Professor

Department of Management, Public Administration and Personnel

West Ukrainian National University

Lvivska str., 11, Ternopil, Ukraine, 46009

I gor Dunayev

Doctor of Sciences in Public Administration, Associate Professor

Department of Economic Policy and Management

Kharkiv Regional Institute of Public Administration of the National Academy of Public Administration under the President of Ukraine

Moskovskyi ave., 75, Kharkiv, Ukraine, 61001

Iryna Petrovska

$\mathrm{PhD}$, Associate Professor, Head of Department**

Olena Mital

$\mathrm{PhD}$, Associate Professor**

Oleksandr Nosyriev

$\mathrm{PhD}$, Associate Professor

Department of International Business and Finance National Technical University "Kharkiv Polytechnic Institute"

Kyrpychova str., 2, Kharkiv, Ukraine, 61002

*Ternopil Ivan Puluj National Technical University Ruska str., 56, Ternopil, Ukraine, 46001 **Department of Hospitality Industry and Sustainable Development V. I. Vernadsky Taurida National University Dzhona Makkeina str., 33, Kyiv, Ukraine, 01042

How to Cite: Ratynskyi, V., Tymoshyk, N., Sherstiuk, R., Dudkina, O., Dunaev, I., Petrovska, I., Mital, O., Nosyriev, O. (2021). Devising scientific and methodological tools to strengthen the economic security of a region through the improvement of technologies for marketing support of tourism. Eastern-European Journal of Enterprise Technologies, 4 (13 (112)), 52-65. doi: https://doi.org/10.15587/1729-4061.2021.238397

\section{Introduction}

The national economic system has undergone significant changes in its composition under the influence of uncon- trollable environmental factors. The corresponding changes took place at the regional level, which caused the deepening of the crisis and led to a reduction of the opportunities for further strengthening of economic security of regional ter- 
ritorial communities, as evidenced by the deterioration of the main socio-economic indicators of development [1]. As a result of destructive changes, the level of social tension increases and living conditions deteriorate, actual production volumes in various sectors of the national economy are reduced, financial flows to budgets of various levels decrease. This narrows the opportunities for infrastructure development negatively affects the investment climate and slows down the pace of economic and innovative development. The restoration of the level of economic security of the regions and the national economy, under such conditions, should be ensured by both the appropriate level of internal factors (stimulation of domestic demand, for example) and corresponding environmental fluids. Internal factors are mostly predictable and controlled compared to macro levels, which are difficult to manage from the regional level. That is why restoration and further strengthening of economic security should be based primarily on taking into consideration and using internal factors. Such sources traditionally include the search and use of reserves for accelerating development in sectors of the economy - industry, agriculture, construction, various types of trade, housing and communal services, communications, the financial sector. Against this background, the role of the tourism business and its potential in ensuring economic growth is practically not considered due to a small contribution to the overall financial and economic result. However, given the multiplicity of types and forms of tourism activities, their relationship with other sectors and sectors of the economy, this direction is promising. It requires more scientific and methodological attention to reveal the opportunities in strengthening economic security and protecting the economic interests of regions and the national economy in general. Under such conditions, appropriate adjustments will require diagnostics of economic security, taking into consideration a set of information on its condition and degree of variability, risks of the obtained results. This will require appropriate changes in the composition and mechanism of implementation of tools for managing the development of tourism business as a potentially important factor in strengthening economic security. Under conditions of rapid development of the information environment, it is the information on the quantity and quality of the tourist product that becomes the basis for its further promotion. That is why the main tools for activating the tourism business should be marketing approaches that ensure the delivery of the corresponding product to the end-user with the greatest efficiency in existing conditions for all subjects of tourist activity.

\section{Literature review and problem statement}

Traditionally, the strengthening of economic security is associated with the development of the domestic market of industrial products, agriculture, communications, the financial sector, etc. An underestimated factor in the formation of economic security remains the development of domestic tourism, which is represented by many directions and diversity of types in all regions of the national economy. According to the estimates of the World Travel and Tourism Council [2], tourism is the third-largest component of gross domestic product, which accounted for $10.4 \%$ in 2019 . The significant potential of tourism is the result of its diversity of types, each of which has characteristic properties that will become a factor in intensifying contribution to economic development. Seasonal summer tourism that is traditional for most citizens can be combined with recreation in ski resorts in winter. The off-season is traditionally filled with numerous weekend tours, as all territorial communities historically have both local and national attractions. The so-called "green tourism" is developing, the use of hunting grounds and fishing waters is in some demand as the way of active recreation, medical and spa tourism is spreading as a challenge to the present in the fight against Covid-19. Paper [3] considers the possibility and features of tourist recreation through active hunting, which affects the state of the ecosystem of a region. The result of the irrational use of natural resources is the deterioration of the economic security of a region by losing income from the implementation of tourist activities. A similar situation can be observed in all regions of the world, where certain sectors of tourism are traditional. Medical business by specialization of separate countries [4], including its variety - spa tourism [5] - can be considered specific but with great expansion prospects. Along with the advantages of generating additional income to the budget and increasing the degree of employment in the correspondent sectors of the economy, there are significant economic disadvantages. An increase in the cost of services for residents and the disparity in the labor market caused by specialization will adversely affect the level of economic security. There emerge new forms of tourism activities, such as sports tourism in those countries where the main business segment is concentrated in the basic mining industry [6]. Such regional development strategy forms the basis for further strengthening of economic security by diversifying activities, which also ensures a reduction in the level of risks. Wild camping is developing as an opportunity for budgetary recreation within your own country [7], which creates additional advantages over other types of tourism. Since this type refers to internal movements, under such conditions there are no outflows of funds outside a region. An important aspect of the intensification of tourist travel is the state and traditions of food of a particular country, which attracts those who can appreciate them [8]. Such a variety of types of tourist products is characteristic of almost all countries, and Ukraine is no exception. However, this factor of accelerating development is used only within $1.4 \%$ to $8.8 \%$ of GDP annually [9], which is much less than the world level and is a reserve for strengthening the economic security of the national economy. Under such conditions, it becomes urgent to develop theoretical and methodological aspects of assessing the impact of the results of the tourist business of regional formations on the general level of their economic security and create further conditions for strengthening. This, in turn, requires the use of appropriate economic tools to support and revitalize the activity of processes related to the implementation of tourist products. Modern economic theory and practice of state and regional management formed a set of such approaches, which ensures the satisfaction of the consumer of a tourist product and achievement of the system of goals of the tourism business. At the same time, they ensure the balance of interests of the region's development by forming and promoting a tourist product along the value creation chain [10].

The marketing concept as one of the approaches to managing the economic security of a region requires the use of both theoretical achievements and practical tools that should complement each other [11]. However, the classic 
postulates of theoretical marketing have certain gaps that were bridged only in recent decades. Such gaps include, in particular, the ability of media to influence the preferences of consumers in terms of meeting specific needs, for example, in tourist travel [12]. Many actual and potential marketing tools need to be clarified in the context of the peculiarities of the modern stage of development of the national economy and its territorial communities, through the prism of the industry structure as well.

Strengthening of economic security of a region as a result of its assessment requires, first of all, clarification of the essence and the structure for further calculations. Until now, there is no single interpretation of the category, which would cover its characteristic features and features of manifestations in various economic systems. Thus, in research [13], the economic security of a region implies the corresponding state of the subsystems of a region in terms of ensuring its (region) progressive development in the context of the influence of negative environmental factors. Economic security, as a system, in accordance with this approach, includes such subsystems as economic, environmental, technological, social, and legal. The subsystems should provide the economy of a region with economic independence in terms of resource control by regional authorities; achieving a certain level of competitiveness of products and services, stability of the regional policy and ability to develop and progress. Assessment of the level of economic security under such conditions should be substantiated with the help of the level of profit of a region. It is advisable to present it in the form of a factor economic model of the appropriate type with wellknown approaches to economic analysis. It is useful to determine the impact of individual factors on changing the overall performance indicator. The use of this approach requires accuracy in the formation of a factor system of the efficiency indicator of a region, which will ensure the adequacy of assessing the impact of certain factors on the level of economic security. This requires appropriate information support in terms of the formation of an array of information on the indicator under study, as well as technologies for achieving the established goal in the aspect of the methods for calculating and using communication tools. However, the author does not specify what kind of profit indicator is meant, which complicates the practical application of this approach. The solution of this important methodological issue, obviously, belongs to the area of the methodology of national accounts and statistics that differ between the countries of the world.

The structure of economic security of a region is slightly different in paper [14], which proposes to include components such as financial (in the context of donor regions and recipient regions), information, investment, innovation and technological, energy, production, socio-demographic, food, environmental. A similar approach is demonstrated in research [15], where they also propose to separate a foreign trade component of the economic security of a region. These studies actually equate all components of the economic security of a region. However, with the development of the market of information and technical methods for its processing, information and communication technologies begin to play a leading role, because they permeate through the components, functions, methods, aims and objectives of economic security of a region. It is the availability of information on the internal and external state of the region's economy that becomes the starting point for the formation of its security. At the same time, it should be emphasized that recently economic accents in this area have shifted towards the overwhelming role of introducing the "brainchildren" of digital technology. The general logic of such scientific and methodological approaches is to structure economic security as a complex socio-economic process, followed by the separation of key indicators that most clearly characterize them in the corresponding works. This, in turn, forms the prerequisites for exercising a controlled impact on them in order to achieve a guaranteed determined result. To do this, it is necessary to determine the quantitative assessment of the level of economic security as the starting point of regulation of the process of its formation, which requires significant amounts of information and appropriate methods of its processing. This demands compliance with certain requirements, the implementation of which ensures the objectivity and independence of evaluation results, namely:

- representativity as a broad scope and reflection of important aspects of economic security of a region;

- accuracy of the quantitative and qualitative level of economic security that is close to actual;

- suitability for use as a tool for further management actions to achieve the set goals of the region development [16].

These requirements fully apply primarily to the information component of the economic security of a region and their effective implementation requires the use of specialized software products aimed at fixing, detailing, and analyzing a sufficient array of data. In this context, it is necessary to emphasize the extremely important issue of determining the goal of economic security of a region, which is the starting point of assessment. It is traditionally presented in the form of protection of economic interests [17], which is advisable to measure with gross regional product or profit as comprehensive generalized economic indicators, as mentioned above.

The issue of quantifying different aspects of economic security of a region and its purpose is the focus of many scientists, for example, in $[18,19]$. The summary of the results of these studies makes it possible to draw a number of conclusions. The list of components and indicators of economic security of a region varies relative to the purpose of the study, as was detailed above regarding the components of economic security. It includes purely economic and traditional financial indicators to generalized groups of indicators. The latter form not only economic essence but also provide an assessment of all components of the macro-, meso- and microenvironment of economic security of a region, including mandatory risk assessment. The latter should include substantiation of evaluation methods, the statistical base of evaluation, and the formation of relevant methodological provisions of various directions in order to achieve the established goals. At the same time, some researchers point out the boundary values of separate groups or separate indicators of economic security in a region. This makes it possible not only to evaluate a separate region among others but also to provide a factor assessment of the results obtained, which creates the basis for further use of the gained experience. A separate issue is a dependence of generalizing assessment of economic security of a region on its components and indicators that form such components. Traditionally, this controversial issue is solved by standardization of statistical procedures for obtaining expert assessments in compliance with the requirements of the need to form independent objective results. To do this, it is enough to use such digital tools as business analysis, big data [20,21], which have the appropriate mathematical tools. In addition, 
their use simplifies the visualization and further application of the obtained results in the system of ensuring the effective economic development of a region through the introduction of innovative information and communication technologies.

For the purposes of this study, we divide all approaches to assessing the economic security of a region into two groups, based on the theoretical and practical possibilities of diagnosing each component of economic security. The principle of dividing approaches is the availability of the criteria of safety assessment for each index of a group of indicators, including the boundary parameters that provide a comprehensive characterization of the economic security of a region.

Numerous studies of the first group represent the economic security of a region in the form of a set of traditional two components - economic and financial. This approach is dictated by the interrelations of the financial results of a region (in the form of a system of absolute and relative indicators) and the economic processes underlying the economic security of a region), for example [22]. The lion's share of such indicators to some extent characterize the gross regional product, without providing thorough detail to other components of the economic security of a region, including the specific features of its position in the state.

Part of the research emphasizes the necessity to separate internal and external components as a division of economic security of a region into components. Such structuring will be the basis for the application of relevant economic management tools in the system of formation and strengthening of economic security [23]. This approach provides a comprehensive assessment of all aspects of the region's economy, in terms of the formation of a general assessment. However, with such a large number of indicators, each of them will not have a significant impact on the overall result, which narrows the possibilities of the wide practical use in quantitative measurement of the strategy and tactics of economic security of a region. Assessment of economic security of a region in the form of a series of macroeconomic indicators [24,25] is also characterized by significant shortcomings, along with the ease of assessment and wide possibilities of practical application. In fact, in these studies, the availability and practical possibilities of using innovative technologies in the industry are considered as the main factor in the formation and development of economic security of a region. This pushed traditional non-industrial regions to the last places in the overall ranking. However, under modern conditions, innovation activity is manifested not only in the industry. New ways of forming and processing information flows are replaced with traditional processes of creation and implementation of innovations, which can change the status quo of industrial regions. That is why the introduction of the latest information and communication technologies becomes a decisive factor in strengthening the economic security of a region.

As a general conclusion on these approaches, it is necessary to point out the complicated procedure for the formation and evaluation of economic security of a region, despite the unquestioning coverage of all its possible aspects. The formation of even such an exhaustive list of comprehensive indicators requires substantiation and application of criteria or threshold values of separate indicators, which is absent in a series of scientific and methodological proposals mentioned above. The achievement of such a task should be facilitated by the wider application of the methods of business analytics $[26,27]$, which is based on large arrays of information of different character, their scope, units of measurement, the rank, evaluation period, etc. This will greatly simplify the rating of regions relative to the level of their economic security according to different criteria positions, depending on the goals of assessment, taking into consideration all the information available at the time of evaluation.

Unlike the assessment of economic security without any regard to the intervals of possible values of each component, a number of researchers of the second group point out the existence of such criteria. Paper [28] presents a substantial description of economic security in terms of financial and economic components with detail on a number of macro-and meso-economic indicators. The minimum requirements for the latter to create the basis for strengthening and further development of a region are also taken into consideration. At the same time, a large share of indicators concerns the introduction of innovations in the production of industrial products, which, as previously noted, narrows the number of objects to which it is advisable to apply scientific and methodological recommendations. The proposals of the author [29], who offers a hierarchy of levels of economic security of depressed regions, are quite interesting. There is also a consideration of innovative and technological factors influencing the level of economic security of a region, but other indicators have a fairly wide scope of application and systematically characterize the non-industrial sector of the national economy. It is worth noting that all analyzed approaches to structuring and assessing the economic security of a region involve the calculation of a large number of indicators. They provide a systemic assessment of all sector components of territorial formation in accordance with the existing system of national accounts and classification of industries or activities, for example, international ISIC or NACE, national CEA [30].

Generalization of the above approaches gives grounds to form restrictions on existing methods of assessing the economic security of a region:

- an excessive number of indicators, the impact of each of which on the overall level of economic security of a region becomes insignificant;

- the lion's share of indicators systematically characterizes the industrial sector of a region (including innovative and inventive, research work), and, accordingly, this technique will give unsatisfactory results for regions where there is no industrial sector;

- part of the indicators has only one threshold value, a significant excess or decrease in which will not be of fundamental importance. However, in practice, there are numerous cases when excessively large or too little value of indicators also provides additional characteristics of the economic security of a region.

\section{The aim and objectives of the study}

The aim of this study is to develop scientific and methodological tools to strengthen the economic security of a region through the revival of the activity of tourism business based on the use of tactical and strategic marketing technologies, taking into consideration the state of development of innovative information and communication technologies.

To achieve the set goal, the following tasks were solved:

- to explore the modern features of the formation of economic security of a region in terms of its content and structuring; 
- to analyze the procedure for its evaluation depending on the methods of evaluation, including the identification of their shortcomings in the further use of the results;

- to establish the composition of administrative and market tools and technologies to activate the tourism industry at the level of a region, business entities, and their associations through the prism of the current state of development of information and communication technologies;

- to consider the diversity of the types of marketing strategies for the development of entities of tourism business and specific features of their implementation at the present stage of development of the digital information environment.

\section{Materials and methods of research}

The theoretical basis of the study is the position of the economic theory, scientific works of national and foreign scientists on the economic security of a region, marketing support of the tourism sector, economic analysis, and diagnosis of economic processes.

In the process of research, we used fundamental (dialectic, systemic) and general scientific methods (formal logic, analysis, and synthesis) in the process of substantiation of the essence of economic security of a region. General scientific methods of cognition were applied: systemic and process approaches to determining the specific features of assessing the economic security of a region. The methods of statistical grouping, logical and comparative analysis were used in the process of researching the approaches to assessing the economic security of a region. The systematization of marketing strategies and tools for activating the tourism business was the result of the use of the methods of formal logic, deduction, and induction.

The methods for economic analysis were used to study the dynamics of economic security of a region. The method of economic and mathematical modeling, correlation, and regression analysis were applied to obtain the parameters of dependence of the potential number of tourists on the limiting factor.

Information and analytical support of research are based on the use of open statistical data.

Taking into consideration the identified shortcomings and limitations of most common methods for assessing the economic security of a region, this study is based on the approach outlined in paper [29], which provides a thorough analysis and division of the concept of economic security of a region into security, threat, and depression. This will make it possible not only to determine the position of a region in the ranking of the level of economic security but also to form clusters of regional entities, in accordance with the three proposed states. The material basis for assessing the economic security of a region is its sector structure, which includes sectors such as agriculture; mining and processing industry; electricity and gas supply; construction; wholesale and retail trade; transport; telecommunications; tourism; public administration and education; healthcare and others.

At the next stage of the creation and development of the territorial formation, the generation of an array of assessments of certain components of economic security of a region will require a generalized conclusion on the sufficiency or insufficiency, risk, threats to external and internal factors of economic security of a region. To do this, it is advisable to use dynamic assessments of the main indicators of economic security of a region, as well as in terms of their exceeding or decreasing in regard to the threshold level. An alternative may be the functional approach, based on the main components of economic security with an appropriate set of indicators [31]. A special place in the research of the level and prospects for strengthening economic security is occupied by multidimensional statistical and econometric analysis, which involves ranking and clustering a set of objects according to the selected criteria [32,33]. The result of the application of the above (one or more) methods is the assessment of economic security in the context of four states with relevant characteristics:

- economic security itself, that is, the ability to further develop the potential of a region, based on the use of internal resources and overcoming external threats, or turning them into their own economic advantages;

- economic risk or partial loss of own advantages with a further reduction of possibilities to ensure economic development of a region;

- economic threat in the form of economic decline with the build-up of a number of conflicts, including those with the external environment;

- economic danger as a characteristic of a deep economic crisis, with a rapid decline in business activity against the background of unregulated influence of the treats of the environment [34].

Comparing this gradation of economic security levels with the boundary levels of its indicators, it can be seen that in this case, the concept of economic security and economic risk falls into the category of "security threshold", in accordance with the principles of assessment [29]. The closer to the threshold level these indicators are, the greater the risk level that is characteristic of the economic security of the studied region. Such joint application of two approaches fully meets the goals of regional and national economic policy in terms of ensuring the desired state of the national economic system in general. It also makes it possible to decide on a set of destructive factors that prevent the achievement of the desired level of goals. The formation of an assessment of the economic security of a region at such levels, taking into consideration the possible variation of its components, requires clarification and corresponding changes in the system of economic security of a region [24].

Theoretical basis and factors of influence on the results of tourist activity are analyzed in numerous papers [32, 35, 36]. The influence of tourism business on the level of economic security is described due to the factors of both controlled and uncontrolled influence (type of economic policy of the state, stage of the economic cycle, etc.). The common denominator of these studies is to increase the role of the state as an equal partner and a stakeholder in the development of the tourist market. Taking into consideration the main goal of economic security of a region - protection of economic interests - the interest of the state to revitalize tourism business is manifested primarily in increasing tax revenues from activities. In addition, the growth of tourist flows in the region will make it possible to identify and widen the "bottlenecks" of the infrastructure, which will give an additional impetus to economic development. The proof of this thesis is the substantiation of a set of principles that can intensify quantitative and qualitative indicators of tourist activity through the implementation of public-private partnership programs [37]. These mechanisms are predominantly administrative in nature and belong to the sphere of activity of regional authorities, but they also require the participation 
of business itself in these processes, since the implementation of public-private partnerships requires the generation, use, and storage of relevant information, which depends on the participants of tourist activities [38-40]. They will be implemented primarily at the regional and national levels. At the level of certain entities of tourist activity, it is advisable to use the mechanisms of joint activity of various forms and directions [41] belonging to the market control methods.

The introduction of scientific and methodological approaches to intensify tourism activities requires at the further stage of management of economic security of a region the development and implementation of technologies of strategic marketing management and planning. This will provide a general vision of the directions and diversity of the types of tourist products for a certain period of planning and forecasting, create preconditions for detailing the formed strategies for current plans and programs. Marketing strategies, which are expedient to use to expand the activities of tourism enterprises, will give an additional impetus to the industry in general and ensure the growth of its contribution to strengthening and developing the economic security of a region.

Marketing strategies should cover all traditional ways to revitalize the business activity of the tourism business. They are based on traditional ways of market development, product, joint activities of various forms of integration and diversification [42, 43], and innovative technologies [44] as ways to revitalize tourist processes in a non-standard way, taking into consideration the achievements of scientific and technological progress.

It should be noted that further development of the strategy and tactics of behavior in the market of tourist services should be based on the results of a thorough analysis of the condition of the entities providing tourist services. At the same time, it is imperative to take into consideration the results of the analysis of the external environment.

Traditionally, micro-media audit technology is represented in the form of detail of the state and prospects of using the resources of an enterprise $[45,46]$. They, in turn, are formed as a result of the implementation of the portfolio of tourist products, which are expedient to form with the help of special software products. These include, in particular, the BITOUR platform [47], which makes it possible to form a tourist offer depending on the preferences and wishes of a client, with minimal time spent by a travel agent. The released time makes it possible to form a financial and economic substantiation for the costs and income from the offer, the implementation of which will significantly affect the internal state of a travel agent.

The research into the macro-environment should be based on thorough studies of such factors and their quantitative indicators characterizing the political and legal situation, economic processes, demographic trends, environmental state, and the use of natural resources [48]. The result of the study of interrelated components of the internal and external environment is traditionally a SWOT-analysis report $[49,50]$. It provides a more detailed assessment of the situation of the tourism sector in terms of available and sufficient resources in it, in the context of the perturbing impact of macro-economic growth.

The use of postulates of the technology of classical SWOT-analysis technology with a detailed diagnosis of its components in the system of formation of marketing strategies of the tourism sector require further detail in terms of tourist products and services of a region (in accordance with the potential number of tourists and their distribution in the market segments). To do this, it is advisable to monitor the components of the "four P" marketing mix - product, price, place, promotion (product/service, pricing strategy/tactics, product market - actual and potential, product promotion channels). However, the recent trends show that the use of the marketing complex in this form has become insufficient. The reason for this is an increase in the requirements of consumers both for the tourist product itself and for its properties, as well as to information support of the process of obtaining and using a tourist service. Taking into consideration such increased requirements, it is proposed to carry out the research into the marketing complex in such additional positions as the physical environment in the process of acquiring the rights for a tourist product (physical evidence). The process of consumption of a tourist product (process), as well as the human factor in the process of choosing a tourist product (people), should be important and relevant. Subjective preferences of a consumer at the time of making a decision on a tourist product (prefer) are becoming increasingly relevant [51,52].

To overcome the crisis phenomena caused by systemic changes in the macroeconomic environment, first of all, it is necessary to use the internal capabilities of the national economy and its regions. Traditional reserves for accelerating economic development and, accordingly, strengthening economic security, are the industrial sector and agriculture, which follows from a detailed analysis of the components of economic security of various researchers, as mentioned earlier. However, to this day, the possibilities of expanding the tourist market due to the growth of domestic tourist flows are almost inexhaustible and underestimated. This would reduce the outflow of funds abroad (by reducing external tourism) and direct them to the comprehensive development of the infrastructure within the national economy. None of the analyzed approaches to assessing the level of economic security of a region in a direct context has the indicators of the state and prospects of development of the tourism sector, as well as the dynamics of infrastructure changes. This requires making appropriate adjustments to ensure the possibility, first of all, of quantitative assessment and the degree of impact of tourism business on the level and prospects of strengthening economic security, taking into consideration the significant potential of the industry. The specifics of tourism activities in the face of rigid environmental tests also require increased attention to the promotion of a tourist product to the end-user. To do this, it is advisable to use the directions of strategic marketing communications. They include advertising using banners, billboards, paper/electronic data carriers. The use of direct marketing tools involves the implementation of Internet marketing in all its diversity, including via television. Such methods for the promotion of a tourist product as personal sales, including training, through public relations, are becoming relevant [53-55]. The suggestion that until recently would surprise potential clients of the tourism business - a virtual tourist trip - seems interesting [56]. However, given the complex epidemiological environment, the impact of which is felt not only by agents of the tourism business, this approach is able to provide a more effective (compared to traditional methods) spread of information about a tourist product. On the other hand, this approach fully meets the goals and objectives of the digitalization of the national economy.

The implementation of the marketing complex, in accordance with these directions, tools and strategies will provide economic security of a region with an additional impetus in strengthening the economic condition and creating the ba- 
sis for further economic growth, in the context of the rapid growth of the influence of information and communication technologies.

\section{Results of research into ensuring marketing processes of tourism business}

\subsection{Results of analysis of the essence and structure} of economic security of a region

Economic security of a region implies such a state of territorial formation, in which its economic interests are ensured and preconditions for further economic development under the influence of a significant amount of information are created.

Protection of economic interests of a region is a defining goal of economic security, which is transformed into a series of key indicators - gross regional product, index of its physical volume, and profit.

The goal of economic security is achieved for the groups of indicators, which should include economic, financial, informational, investment, innovative, technological, energy, production, socio-demographic, and food components, which systematically cover all aspects and processes of economic security of a region. These components are the factors that influence the overall level of economic security, which is proposed to be diagnosed at four levels: economic security, economic risk, economic threat, and economic danger with appropriate levels of criterion indicators.
According to the obtained results of the dynamics of economic security, it is necessary to draw the following conclusions:

- the export-import component of the economic security of a region fell into the "security" segment, that is, the relevant components are present in sufficient quantity and quality to ensure further economic development of a region;

- investment and innovation component, represented by the levels of investment in fixed capital, depreciation of fixed assets, and the share of innovative products, is insufficient and fell into two segments "depression" and "threat";

- analysis of the relations between the budget of a region and the state budget gives the basis for a positive conclusion on the security of a region in terms of correlation with the gross regional product as a generalized financial and economic indicator of the security level.

Such ambiguity of the obtained results requires additional monitoring of the gross regional product, which is the basis for calculating the above indicators. The analysis of the cost level of the indicator gives grounds for an optimistic conclusion on the economic security of a region, taking into account a steady growth trend during 2004-2019 [35]. However, this result may be due to the impact of the price level, so it is advisable to analyze the change in the physical volume index of the gross regional product - Fig. 1 .

\section{2. Estimating the economic security of a region}

It is advisable to assess the economic security of a region using one of such methods as the use of dynamic estimates, the use of methods of multidimensional statistical data analysis, or the econometric method of modeling economic processes.

In the process of monitoring economic security using various evaluation methods, it is necessary to ensure the clarity of obtained results obtained, their accuracy, and suitability for further use as a result of the implementation of the evaluation principles.

The application of the most effective approach to assessing the economic security of a region on the example of Zaporizhzhia Oblast, which has significant industrial and agricultural potential, as well as significant tourist resources of various orientations, was considered. The obtained results are shown in Table 1.

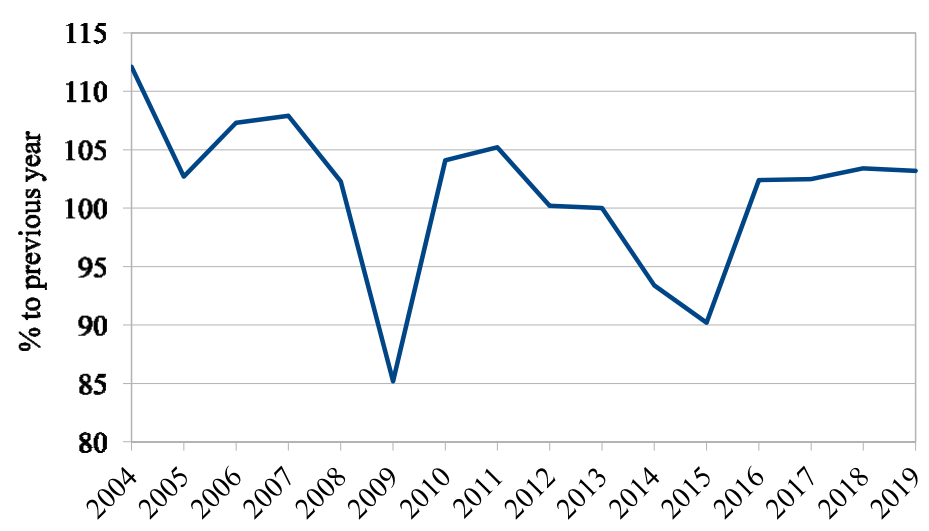

Fig. 1. Dynamics of the index of physical volume of the gross regional product of Zaporizhzhia Oblast, \%

Table 1

Identification of economic security of Zaporizhzhia Oblast

\begin{tabular}{|c|c|c|c|c|c|c|c|c|c|c|c|}
\hline & \multirow{2}{*}{$\begin{array}{c}\text { Indicators } \\
\text { threshold }\end{array}$} & \multirow{2}{*}{$\begin{array}{c}\text { Threat } \\
\text { threshold }\end{array}$} & $\begin{array}{c}\text { Depression } \\
\text { threshold }\end{array}$ & \multicolumn{5}{|c|}{ Years } \\
\cline { 6 - 13 } & & & 2012 & 2013 & 2014 & 2015 & 2016 & 2017 & 2018 & 2019 \\
\hline Coefficient of covering export by import & $\geq 1$ & $0.8-1$ & $<0.8$ & 1.97 & 2.09 & 2.36 & 2.70 & 2.30 & 2.24 & 1.91 & 2.01 \\
\hline Export share in gross regional product, \% & $\geq 50$ & $40-50$ & $<40$ & 58.2 & 54.1 & 67.2 & 71.9 & 56.2 & 60.8 & 62.5 & 52.0 \\
\hline Import share in GRP of a region, \% & $\leq 50$ & $50-62.5$ & $>62.5$ & 29.6 & 25.9 & 28.5 & 26.6 & 24.5 & 27.1 & 32.6 & 25.5 \\
\hline Investments in fixed capital, \% of the GRP & $\geq 20$ & $16-20$ & $<16$ & $\mathrm{x}$ & 12.6 & 10.7 & 8.8 & 10.6 & 12.2 & 10.7 & 9.6 \\
\hline Level of depreciation of main facilities, \% & $\leq 50$ & $50-62.5$ & $>62.5$ & $\mathrm{x}$ & $\mathrm{x}$ & 83.5 & 60.1 & 58.1 & 55.1 & 60.6 & 56.9 \\
\hline $\begin{array}{c}\text { Share of realization of innovative product in } \\
\text { volume of industry, \% }\end{array}$ & $\geq 15$ & $12-15$ & $<12$ & 2.2 & 2.3 & 1.7 & 2.6 & $\mathrm{x}$ & 2.4 & $\mathrm{x}$ & 1.6 \\
\hline $\begin{array}{c}\text { Volume of transfers from the state budget, \% } \\
\text { of the GRP }\end{array}$ & $\leq 5$ & $5-6.3$ & $>6.3$ & 4.9 & 5.2 & 4.7 & 4.8 & 4.9 & 5.5 & 5.1 & 3.8 \\
\hline
\end{tabular}

Note: $x$ - the data are not available 
Taking into consideration the presented dynamics, it is necessary to prove the conclusion about the lack of resources and results in order to get into the "security" segment. These figures show unstable fluctuations in the physical indicator of economic security, while cost indicators show growth. Periods within 2008-2009 and 2014-2015 are characterized by a rapid reduction in the volume of produced gross regional product, which has not yet been overcome since the level of 2004 has not yet been reached. Given these circumstances, it is necessary to summarize that the conclusion that the indicators of economic security of a region fall into the segments of "depression"/"threat" according to various indicators during the analyzed period is proved.

The existing actual and potential opportunities for expanding the tourist services market were evaluated. According to official statistics, the number of collective accommodation facilities decreased from 312 units in 2011 to 133 units in 2019 [35]. The dynamics of the number of holidaymakers accommodated at these institutions are shown in Table 2. Additionally, the load factor is given as the ratio of the number of holidaymakers in collective accommodation facilities to their number served by tour operators.
- the general dynamics of the number of tourists served by tour operators within the analyzed period stabilized taking into consideration two periods of reduction of tourist flows in 2012 and 2015. However, it has not yet been possible to reach the level of 2011;

- representation of the load coefficient in the Table shows the gap between the actual number of tourists visiting the region and their share, which was serviced by tour operators. That is, the actual number of visits to the region will always be on average 6 times higher than the official number (from tour operators); the overall fluctuation of the indicator was diagnosed at the level from 2.9 to 8.5 times.

According to the results of the presented dynamics, it should be noted that, despite the formation of prerequisites for positive dynamics, there is a slowdown in the rate of reduction in the number of holidaymakers. Under such conditions, it is necessary at least to keep the existing positions without losing the quality of tourist services. It is necessary to clarify and rethink the scientific and methodological basis for the implementation of tourist activities under conditions of the external environment, which is rapidly and unpredictably deteriorating, and accordingly, affects the prospects of the internal state of the region.

Table 2 5. 3. Administrative and

Dynamics of the number of holidaymakers in collective accommodation facilities and health care institutions of the Zaporizhzhia Oblast, people

\begin{tabular}{|c|c|c|c|c|c|c|c|}
\hline Years & $\begin{array}{c}\text { Humber } \\
\text { of health } \\
\text { care insti- } \\
\text { tutions, } \\
\text { units }\end{array}$ & $\begin{array}{c}\text { Number } \\
\text { of places in } \\
\text { health care } \\
\text { institutions, } \\
\text { units }\end{array}$ & $\begin{array}{c}\text { Number of } \\
\text { collective } \\
\text { accommoda- } \\
\text { tion facilities, } \\
\text { units }\end{array}$ & $\begin{array}{c}\text { Number of peo- } \\
\text { ple that visited } \\
\text { collective ac- } \\
\text { commodation } \\
\text { facilities }\end{array}$ & $\begin{array}{c}\text { Load on } \\
\text { collective } \\
\text { accommoda- } \\
\text { tion facilities, } \\
\text { units }\end{array}$ & $\begin{array}{c}\text { Number } \\
\text { of tourists, } \\
\text { serviced by } \\
\text { tourist opera- } \\
\text { tors, people }\end{array}$ & $\begin{array}{c}\text { Load } \\
\text { co- } \\
\text { effi- } \\
\text { cient }\end{array}$ \\
\hline 2011 & 219 & 32400 & 312 & 263100 & 843.3 & 60055 & 4.4 \\
\hline 2012 & 226 & 29600 & 315 & 302159 & 959.2 & 35428 & 8.5 \\
\hline 2013 & 232 & 29600 & 358 & 287319 & 802.6 & 54415 & 5.3 \\
\hline 2014 & 230 & 30700 & 355 & 283468 & 798.5 & 39010 & 7.3 \\
\hline 2015 & 225 & 29000 & 311 & 261965 & 842.3 & 30922 & 8.5 \\
\hline 2016 & 262 & 33100 & 376 & 309505 & 823.2 & 40376 & 7.7 \\
\hline 2017 & 243 & 32200 & 374 & 319594 & 854.5 & 47675 & 6.7 \\
\hline 2018 & $\times$ & $\times$ & 123 & 162299 & 1319.5 & 56374 & 2.9 \\
\hline 2019 & $\times$ & $\times$ & 133 & 172731 & 1298.7 & 56838 & 3.1 \\
\hline $\begin{array}{c}\text { Average } \\
\text { level }\end{array}$ & 233.9 & 30942.9 & 295.2 & 262460 & 949.0 & 46788 & 6.0 \\
\hline
\end{tabular}
market regulation of tourism business activization

Being the third most influencing sector (after industry and agriculture) on the state of economic security of a region, the tourism sector needs transformation of marketing technologies to its intensification and increase in contribution to the overall result. For this purpose, a number of administrative tools for the revitalization of the situation, which aims at activization of the state as an equal partner and guarantor at the international level, are proposed. They will expand the capabilities of tour operators and travel agents by attracting additional resources through such mechanisms as:

According to the results of the Table, it is necessary to draw a number of the following conclusions on the trends, prospects, and potential of the tourism industry of Zaporizhzhia Oblast:

- within the period of 2011-2019, the number of collective accommodation facilities decreased significantly from 312 in 2011 to 133 units in 2019. However, the load on the remaining facilities increased substantially from 843 people in 2011 to almost 1,299 people in 2019. Such a situation requires intervention in order to substantiate the actual and potential opportunities for further similar implementation of tourist activities without decreasing its quality and load on the infrastructure facilities;

- dynamics of the state and structure of the number of health institutions indicates a certain increase in their number with the simultaneous stabilization of the flow of holidaymakers, taking into consideration the fact that for the period 2018-2019, there is no official data on these positions;

- optimization of the structure of tourism sector management, including substantiation of methodological aspects of implementation;

- attraction of international technical assistance, including grant programs of different orientations and countries of origin that will introduce systematic cooperation with leading countries, which will provide additional experience in doing business.

Along with administrative methods, the activation and growth of the role of the tourism business is the result of the influence of market mechanisms, thus, it is proposed to separate a wider application of cooperation of entities of the tourism industry. It will provide significant financial and economic benefits to each of the entities due to:

- optimization of costs for the maintenance of tourist facilities and transportation of tourists through the redistribution of constant and variable costs between enterprises 
providing tourist services, such as loading temporarily available places in the network of tourist enterprises;

- obtaining immediate overall information on the state and prospects of the tourist market, based on the creation of a single information field of cooperation between tour operators, their agents, etc.;

- formation and use of a system of financial support for cooperation members through the allocation of temporarily available funds to support the entities that immediately need them on more favorable return terms than those offered by banks. This, in turn, will be able to strengthen the state of financial and economic security of a separate member of the cooperation, by reducing the financial costs and time associated with the search, attraction, and use of financial resources.

\section{4. Systematization of marketing strategies of tour-} ism business

Further application of the principles of activities of associations of tourism business enterprises requires the creation and implementation of marketing strategies. It is advisable to group the traditional marketing strategies of the tourism business as follows: concentrated growth, integrated growth, diversified growth, and compliance with customer expectations.

Concentrated growth strategies should include the expansion of the activities of associations of tourist enterprises due to:

- creation of new tourist products;

- stimulation of the sale of an existing product portfolio;

- expansion of the tourist product market or by starting related activities.

The association principle that was discussed earlier is at the heart of integration as one of the marketing strategies of the tourism business. It is advisable to create associations in the tourism business by: merging and taking over tourism entities; cooperating the efforts of various participants in the tourism business; or creating new areas of tourist activity along with existing ones.

Strategies for diversified growth of tourism activities are more beneficial than those mentioned above by a significant decrease in risks. They involve the creation and maintenance of economic activity, different from the existing processes, or opening new markets with new types of products (goods, services, work).

Under conditions when the above-mentioned strategies for the development of the tourism business do not give the expected positive results, the entity of tourist activity can devise a strategy to meet the expectations of the core customers. In this case, more painstaking work with market niches or orientation to the requests of the highest price segment is required. It is also advisable to focus on mass flows of tourists - this will require differentiation of tourist flow by groups of mass requests, according to the segments of the target audience.

The above-mentioned strategies do not apply the capabilities and achievements of scientific and technological progress and the latest methods of planning further activities. Under modern conditions, competition becomes more rigid and leads to the need to constantly adjust traditional marketing strategies, which sometimes do not give the desired result. In this case, most tourist companies pay attention to the so-called "technological" update of the portfolio of strategies and tactics to achieve the set goals. This approach fully complies with the established mandatory innovative component of the economic security of a region. Innovations will make it possible to effectively achieve the goal and form a set of advantages against the background of tourist enterprises in other regions. The relevant marketing technologies will be chosen depending on the scale of activity of tourist enterprises or their cooperation - the primary market strategy. The maneuverability of the management system as a feature and advantage requires the choice of the leader following strategy. The availability of opportunities for operational changes in the technology of activity and the state of use of resources and the level of costs of an enterprise best corresponds to the strategy of copying a tourist product.

The innovative primary market strategy is characterized by high risk, which is justified when there are opportunities to use their own financial resources and the ability to attract third-party resources both at the regional level and in international cooperation programs. Following-the-leader strategy, first of all, should provide for the availability of opportunities for rapid response according to the strategy and tactics of the leader of the tourist market, based on material, technical, financial, and marketing opportunities for copying or creating a modified tourist product. Copying a tourist product will require minimal (compared to the above) financial costs, due to advance knowledge of the desired characteristics of a tourist product. The introduction of these innovative technologies in achieving the goals of economic security of a region will require the use of new information technologies in the first place, since the ways to achieve them involve the generation of significant amounts of new information on the features of the proposed tourist products.

The formation and implementation of marketing strategies require, first of all, a comprehensive assessment of the state of the industry. To do this, it is proposed to supplement the SWOT diagnostic technology with estimates of the parameters of the degree of influence on the activities of the tourism business and the probability of the relevant components. The main states of economic security include economic security, economic risk, economic threat, economic danger, as mentioned earlier. Then the technology of traditional SWOT analysis should be supplemented by a thorough diagnosis of the characteristics of the components, in terms of the degree of their impact and probability of implementation in the short, medium, and long term. This will reveal those positions that will require priority attention and appropriate actions in accordance with the economic security goals of a region - in accordance with the Pareto principle (approximately $70 \%$ of positions). The other $20 \%$ factors of environmental impact and internal factors will require secondary attention, depending on available resources and management tools. All remaining impact factors will require episodic monitoring in order to know in advance how to transfer them to the first two sectors. It is advisable to assess the internal potential of the tourism business using specialized programs that are able to ensure the formation of a tourist offer - BITOUR.

The main indicator that systematically characterizes the internal environment of the tourism business, and which is the basis for the development of strategic plans, is an indicator of the number of people serviced by a tourist operator. However, as the results of monitoring of the tourist market (Table 2) showed, the actual number of people involved in tourist processes is much higher than the described 
indicator (on by the magnitude of load coefficient, on average, 6 times as high). The explanation of the phenomenon is simple - similarly to the self-employment, population plans their vacation without addressing travel agents and tour operators. Under such conditions, the forecast of the potential number of tourists should be based on the number of people registered in collective accommodation facilities. A critical factor limiting this process is the number of such institutions, which is why we will carry out economic and mathematical modeling of the potential number of tourists in Zaporizhzhia Oblast according to the following economic and mathematical model:

$$
P N T=f(N c a f),
$$

where $P N T$ is the potential number of tourists, people per year; Ncaf is the number of collective accommodation facilities, units.

Using the data of Table 2, we get the following results shown in Table 3.

which involve substantiation of dynamics of macroeconomic indicators, this algorithm allows making the final conclusion based on one of the basic indicators (gross regional product, index of physical volume of gross regional product, profit indicators). These indicators take into consideration the change in both cost factors and assess the impact of physical volumes of activity. The reasons for this condition are revealed through partial indicators based on taking into account the structure of the region's economy in terms of industries, activities, etc.

The application of dynamic estimates of economic security of a region is an easy-to-use technique that does not require the application of the latest information and communication technologies. However, this simplicity is associated with a significant drawback - the obtained estimates for the above components must be summarized by searching for causal relationships. The use of multidimensional statistical analysis eliminates this disadvantage, however, in turn, it will require a higher quantity and quality of calculations in order to justify the level of economic security. The calculations made on the Table 3

Results of economic and mathematical modeling of the potential number of tourists of Zaporizhzhia Oblast

\begin{tabular}{|c|c|c|c|}
\hline $\begin{array}{c}\text { No. by } \\
\text { order }\end{array}$ & $\begin{array}{c}\text { Type of de- } \\
\text { pendence }\end{array}$ & Economic and mathematical model & $\begin{array}{c}\text { Determina- } \\
\text { tion factor, \% }\end{array}$ \\
\hline 1 & linear & $P N T=-11,507.8 \times N c a f+319,999.1$ & 30.3 \\
\hline 2 & exponential & $P N T=335,395.7 \times \exp (-0.0541 \times N c a f)$ & 35.1 \\
\hline 3 & logarithmic & $P N T=-30,639.7 \times \ln (N c a f)+306,042.6$ & 14.8 \\
\hline 4 & polynomial & $P N T=-791.3 \times N c a f^{3}+6,760.4 \times N c a f^{2}-10,427.9 \times N c a f+278,560.2$ & 64.4 \\
\hline 5 & stepwise & $P N T=316,067.4 \times N c a f^{-0.149}$ & 18.2 \\
\hline
\end{tabular}
region with strong components of economic security (Table 1, Fig. 1) proved the need to apply dynamic estimates, first of all. They characterize not only the current state, but also provide the basis for further forecasting of the situation. At the same time, a necessary and sufficient condition for the

According to the results of conducted modeling, the polynomial model, which by $64.4 \%$ describes the logic of dynamics of the potential number of tourists depending on the state of the infrastructure (the number of collective accommodation facilities), should be considered the best one:

$$
\begin{aligned}
& P N T=-791.3 \times N c a f^{3}+6,760.4 \times N c a f^{2}- \\
& -10,427.9 \times N c a f+278,560.2 .
\end{aligned}
$$

Thus, the implementation of the obtained economic and mathematical model will make it possible not only to plan the number of tourists but also to model the desired state of the infrastructure of a region (taking into consideration their variations in accordance with the initial modeling base). This will make it possible to clarify strategic and tactical plans and programs for the development of tourism business, and as a result, to assess its contribution to strengthening economic security.

\section{Discussion of results of devising the concept of tourism business marketing in strengthening the economic security of a region}

Assessment of economic security as a result of protection of economic interests of a region allows making a general conclusion on its condition in terms of achieving certain results: economic security, economic danger, economic risk, and economic threat. Unlike numerous studies [14, 18, 19, 34], assessment is a simultaneous combination of the general indicator with its partial levels. This approach ensures the identification of factors of negative and positive impact on the current state of a region, which remain unrevealed in the methodological aspect of research, for example [23,31].

Analysis of dynamics of tourist flows in a region ( $\mathrm{Ta}-$ ble 2) proved the need to improve the mechanism of regulation of tourist activity in terms of both administrative tools and market control. These mechanisms have an impact not alone but in mutual preconditions and relations. The implementation of this principle will ensure the synergistic effect of their interaction, which will create preconditions for the intensification of tourist processes. The use of only some or other levers of influence is insufficient to revitalize the tourism industry due to the openness of the national economy and the need to provide social guarantees to the population under conditions of market relations.

The logical continuation of the implementation of market mechanisms for managing the tourism industry - cooperation mechanisms - is a wider application of marketing strategies in the tourism industry. Since the mechanisms of cooperation of activities provide a number of advantages, it seems natural to use various strategies both of traditional directions of growth of the tourism business through integration or diversification, as well as innovation direction. This fully corresponds to the main factors of formation and strengthening of economic security of a region in terms of the main indicators, including the innovative basis of a region (Table 1, the share of innovative products in the volume 
of industrial products). The basis for marketing strategic planning is the substantiation of the volume of provided services, based on forecasting the potential number of tourists. For this purpose, economic and mathematical modeling of the corresponding dynamics of tourists was carried out, see formula (2). Expectedly, the polynomial dependence as a general view of dynamics of economic cycles of the region's development is the closest to the actual dynamics of the tourism business. The tourism sector, as well as the economy of a region in general, is also characterized by the cyclical nature of development, which is reflected in the model and is equal to the determination factor.

The obtained scientific results on the intensification of the tourism sector provide a methodological basis for increasing its contribution to the formation and strengthening of the economic security of a region. This becomes possible due to the use of a number of market tools at the level of associations of enterprises providing tourist services - marketing strategies of the tourism business. Increased business activity of the tourism sector, thus, will provide additional revenues to the budget of a region, generation of additional jobs in the industry, development of tourism-associated infrastructure. This will create the basis for strengthening economic security or its transfer to a higher level, for example, from economic danger to economic threat or risk.

The practical significance of the completed study is proved by the performed diagnosis of the general level of economic security of Zaporizhzhia Oblast on the use of the system of indicators and the generalizing indicator. The state of the tourism business of a region was analyzed and an economic and mathematical model for forecasting the potential number of tourists was developed, which makes it possible to work out marketing strategies of the industry and increase its contribution to strengthening the economic state of a region.

Analyzing the content of the author's concept, it is necessary to consider the fact that outside the research, there were problems of identification of components of economic security and their mathematical reducing to the resulting indicator. This somewhat limits the development of a methodical approach to calculating the level of economic security despite the proposed levels (economic security, economic risk, economic threat, economic danger). However, this creates the basis for further research. Methodical limitation concerns the quantitative measurement of the impact of tourist business results on the overall level of economic security in the context of groups of its indicators, generalizing results, and proposed levels.

At the same time, the proposed approach is not without flaws. They include the authors' positions regarding the composition of key indicators of economic security in a region. Given the complexity and extremely high structure of the determined category, it is impractical to boil down its quantitative assessment to one indicator. It is necessary to apply the considered system of the groups of indicators, which should be filled with appropriate indicators. Insufficient attention to the mechanism of assessing the contribution of tourism business to the overall assessment of the economic security of a region somewhat narrows the possibilities and directions of application of the proposed approach. However, these positions do not degrade the theoretical significance of the study.

The development of further research, initiated by this publication, involves further deepening theoretical devel- opments on devising the evaluation principles and features of various methods for assessing the economic security of a region under the influence of various factors. Assessment of the contribution of the tourism sector to the level of economic security of a region will require further assessment of the quality of the relevant economic and mathematical forecasting model, its approbation and determining the features of assessment of external and internal factors that were not included in the model. The scientific and methodological provisions on the structuring of economic security for four states (security, danger, risk, threat) require further clarification. The theoretical basis of innovative information and communication technologies will be deepened in the direction of the mechanism of choosing between separate software products, such as taking into consideration their costs, significance in a particular country, in a particular region, or a network of enterprises.

\section{Conclusions}

1. Economic security of a region should be based on ensuring the economic interests of a region and at the same time create a basis for further economic development Momentary and interval indicators, such as gross regional product, index of physical volume of gross regional product, profit, should be used to assess the achievements of the set goals. The formulation and achievement of the established goal require the aggregation of typical socio-economic processes in groups, such as economic, financial, information, investment, innovative, technological, energy, production, socio-demographic, and food components. This makes it possible to systematically cover the components of the economic security of a region. They (components) influence the overall level of economic security, the results of which are proposed to be diagnosed at four levels: economic security, economic risk, economic threat, and economic danger with appropriate levels of criterial indicators.

2. The procedure for assessing economic security is based on the use of such traditional methods as monitoring the dynamics of indicators and indices, econometric and multidimensional statistical analysis, predictive economic and mathematical modeling. They provide clarity of results, their accuracy, and suitability for further use. The information generates related flows covering all these aspects from the stage of goal setting to obtaining specific results of its achievement.

3. The tourism sector, as an important component of the economic security of a region, requires the transformation of marketing approaches in order to increase the contribution of the industry to the overall level of sustainability and dynamics of economic development. For this purpose, a number of administrative regulatory tools, the implementation of which will expand the role of the state as an equally effective partner in tourism, were proposed. In the market environment, the intensification of tourist processes also requires a wider application of market mechanisms, namely, the processes of cooperation of entities of the tourism industry, which will provide a number of economic benefits based on joint activities. This subsequently requires the implementation of a system of marketing strategies based on traditional and innovative ways to ensure economic growth and development. 
4. The formation and implementation of these strategies will be based on the results of the technology of SWOT-diagnosis of the industry with an assessment of parameters of the degree of impact and probability of the relevant components, which makes up the diagnosis of the external environment. Assessment of the potential and capabilities of the internal state will be based primarily on the portfolio of tourist products. It is advisable to form it with the help of digital technologies, namely the BITOUR. This will create clarity for a potential client, as well as provide a greater likelihood of accepting a tourist offer.

\section{References}

1. Statystychna informatsiya. Rehionalna statystyka. Valovyi rehionalnyi produkt. Derzhavna sluzhba statystyky Ukrainy. Available at: http://ukrstat.gov.ua/

2. Economic impact reports. World Travel \& Tourism Council. Available at: https://wttc.org/Research/Economic-Impact

3. Wilfred, P., MacColl, A. D. C. (2016). Status of wildlife at trophy hunting sites in the Ugalla Game Reserve of Western Tanzania. Tropical Conservation Science, 9 (3), 194008291666733. doi: https://doi.org/10.1177/1940082916667336

4. Beladi, H., Chao, C.-C., Ee, M. S., Hollas, D. (2017). Does Medical Tourism Promote Economic Growth? A Cross-Country Analysis. Journal of Travel Research, 58 (1), 121-135. doi: https://doi.org/10.1177/0047287517735909

5. Pinos Navarrete, A., Shaw, G. (2020). Spa tourism opportunities as strategic sector in aiding recovery from Covid-19: The Spanish model. Tourism and Hospitality Research, 21 (2), 245-250. doi: https://doi.org/10.1177/1467358420970626

6. Theodoropoulou, I., Alos, J. (2020). Expect amazing! Branding Qatar as a sports tourism destination. Visual Communication, 19 (1), 13-43. doi: https://doi.org/10.1177/1470357218775005

7. Rantala, O., Varley, P. (2019). Wild camping and the weight of tourism. Tourist Studies, 19 (3), 295-312. doi: https:// doi.org/10.1177/1468797619832308

8. Rousta, A., Jamshidi, D. (2020). Food tourism value: Investigating the factors that influence tourists to revisit. Journal of Vacation Marketing, 26 (1), 73-95. doi: https://doi.org/10.1177/1356766719858649

9. V 2019 godu inostrannye turisty ostavili v Ukraine $\$ 1,4$ milliarda (infografika). Available at: https://minfin.com. ua/2020/06/01/46399442/

10. Chandy, R. K., Johar, G. V., Moorman, C., Roberts, J. H. (2021). Better Marketing for a Better World. Journal of Marketing, 85 (3), 1-9. doi: https://doi.org/10.1177/00222429211003690

11. Deighton, J. A., Mela, C. F., Moorman, C. (2021). Marketing Thinking and Doing. Journal of Marketing, 85 (1), 1-6. doi: https:// doi.org/10.1177/0022242920977093

12. Sheth, J. N. (2020). Borderless Media: Rethinking International Marketing. Journal of International Marketing, 28 (1), 3-12. doi: https://doi.org/10.1177/1069031x19897044

13. Semenets, A. A., Tyurina, D. M. (2015). Problems in providing factor analysis of region's performance in the context of economic security monitoring. Actual Problems of Economics, 1, 285-291.

14. Bilousov, E. (2014). The essential characteristics of correlation the concept of «economic security of the state», «economic security of the region», «economic safety of the enterprise». Pravo ta innovatsiyi, 1-2, 21-25.

15. Pilko, A. D., Savchuk, N. V. (2016). Determining the Threshold Levels of Economic Security of the Region's Territorial Systems on the Basis of Models of Discriminant Analysis and Euclidean Distance. Problemy ekonomiky, 3, 307-313.

16. Bukolova, V. V. (2018). Preconditions of evaluating social-economical security of a region. Uzhorod National University Herald. International Economic Relations and World Economy, 17 (1), 29-33.

17. Ivaniuta, V. V. (2020). Ensuring economic security at the regional level as a state influence direction. Economics, Management and Administration, 2, 69-73. doi: https://doi.org/10.26642/ema-2020-2(92)-69-73

18. Gontar, A. (2018). Ensuring economic safety: regional aspects. Proceedings of the International Scientific Conference "Competitive, Sustainable and Secure Development of the Regional Economy: Response to Global Challenges” (CSSDRE 2018). doi: https:// doi.org/10.2991/cssdre-18.2018.149

19. Kiseleva, I. A., Nevrov, I. I., Pikalov, A. V., Iskajyan, S. O., Tramova, A. M. (2019). Economic safety of the regions: Technology, trends, and risks. International Journal of Recent Technology and Engineering, 8 (3), 5572-5579. doi: https://doi.org/10.35940/ ijrte.c5529.098319

20. Lavalle, A., Mate, A., Trujillo, J., Rizzi, S. (2019). Visualization Requirements for Business Intelligence Analytics: A Goal-Based, Iterative Framework. 2019 IEEE 27th International Requirements Engineering Conference (RE). doi: https://doi.org/10.1109/ re.2019.00022

21. Zheng, Z. (Eric), Fader, P., Padmanabhan, B. (2012). From Business Intelligence to Competitive Intelligence: Inferring Competitive Measures Using Augmented Site-Centric Data. Information Systems Research, 23 (3-part-1), 698-720. doi: https:// doi.org/10.1287/isre.1110.0385

22. Kozmuk, N., Gupalo, M. (2018). Baseline assessments of the financial and economic safety of regions of Ukraine. Visnyk Universytetu bankivskoi spravy, 2, 40-46. 
23. Marhasova, V. (2015). Ekonomichna bezpeka rehionu. Hlobalne upravlinnia ta ekonomika, 1, $206-210$.

24. Pivavar, I. V. (2019). The Methodology of Research on the Unevenness in Development as a Factor of Ensuring the Economic Security of Regions of Ukraine. Business Inform, 4, 147-157. doi: https://doi.org/10.32983/2222-4459-2019-4-147-157

25. Tymchyshyn, J. V. (2019). The Instrumentarium to Explore Approaches to the Economic Security of Regions. Business Inform, 6, 83-88. doi: https://doi.org/10.32983/2222-4459-2019-6-83-88

26. Rikhardsson, P., Yigitbasioglu, O. (2018). Business intelligence \& analytics in management accounting research: Status and future focus. International Journal of Accounting Information Systems, 29, 37-58. doi: https://doi.org/10.1016/j.accinf.2018.03.001

27. Bordeleau, F.-E., Mosconi, E., de Santa-Eulalia, L. A. (2019). Business intelligence and analytics value creation in Industry 4.0: a multiple case study in manufacturing medium enterprises. Production Planning \& Control, 31 (2-3), 173-185. doi: https://doi.org/ 10.1080/09537287.2019.1631458

28. Bogdan, N. M. (2018). Assessing the Level of Financial and Economic Security of Ukraine's Regions: Methodology and Practice. The Problems of Economy, 1, 142-149.

29. Kupyra, M. I. (2017). Evaluation level of economic security depressed regions of Ukraine. Ekonomichnyi forum, 2, $124-129$.

30. Provisional central product classification. Available at: https://unstats.un.org/unsd/classifications/Econ/Download/In\%20Text/ CPCprov_english.pdf

31. Kozachenko, G. V., Bukolova, V. V. (2018). The Analysis of Approaches to Assessing Socio-Economic Security of a Region. The Problems of Economy, 1, 150-157.

32. Antonakakis, N., Dragouni, M., Eeckels, B., Filis, G. (2017). The Tourism and Economic Growth Enigma: Examining an Ambiguous Relationship through Multiple Prisms. Journal of Travel Research, 58 (1), 3-24. doi: https://doi.org/10.1177/0047287517744671

33. Chen, J. L., Li, G., Wu, D. C., Shen, S. (2017). Forecasting Seasonal Tourism Demand Using a Multiseries Structural Time Series Method. Journal of Travel Research, 58 (1), 92-103. doi: https://doi.org/10.1177/0047287517737191

34. Onyschenko, V. O., Bondarevska, O. M. (2018). A Protective Approach to Determining Economic Security of a Region. The Problems of Economy, 1, 158-164.

35. Calero, C., Turner, L. W. (2020). Regional economic development and tourism: A literature review to highlight future directions for regional tourism research. Tourism Economics, 26 (1), 3-26. doi: https://doi.org/10.1177/1354816619881244

36. Bronner, F., de Hoog, R. (2017). Tourist Demand Reactions: Symmetric or Asymmetric across the Business Cycle? Journal of Travel Research, 56 (7), 839-853. doi: https://doi.org/10.1177/0047287516672347

37. Zakharin, S. (2018). Organizational and Economic Factors for Development of Tourism and Resorts in Ukraine. Bulletin of Kyiv National University of Culture and Arts. Series in Tourism, 2, 57-66. doi: https://doi.org/10.31866/2616-7603.2.2018.154435

38. Mandal, S. (2018). Exploring the influence of big data analytics management capabilities on sustainable tourism supply chain performance: the moderating role of technology orientation. Journal of Travel \& Tourism Marketing, 35 (8), $1104-1118$. doi: https://doi.org/10.1080/10548408.2018.1476302

39. Inanc-Demir, M., Kozak, M. (2019). Big Data and Its Supporting Elements: Implications for Tourism and Hospitality Marketing. Big Data and Innovation in Tourism, Travel, and Hospitality, 213-223. doi: https://doi.org/10.1007/978-981-13-6339-9_13

40. Yallop, A., Seraphin, H. (2020). Big data and analytics in tourism and hospitality: opportunities and risks. Journal of Tourism Futures, 6 (3), 257-262. doi: https://doi.org/10.1108/jtf-10-2019-0108

41. Vyslobodska, H., Makarukha, S. (2019). Tourism cooperation: state, problems and prospects. Black Sea Economic Studies, 47-1, 126-130. doi: https://doi.org/10.32843/bses.47-23

42. Okhota, V. I. (2019). Modern competitive strategies on increasing domestic tourist flows. Innovative Economy, 3-4, $107-113$.

43. Sert, A. N. (2017). Niche Marketing And Tourism. Journal of Business Management and Economic Research, 1 (1), 14-25. doi: https://doi.org/10.29226/jobmer.2017.1

44. Koveshnikov, V. S., Popovich, K. V. (2015). Problems of technological innovation in tourism. Heohrafiya ta turyzm, $34,64-75$.

45. Nechyporuk, S. V. (2012). Orhanizatsiyne ta metodychne zabezpechennia stratehichnoho planuvannia marketynhu na pidpryiemstvakh hotelnoho hospodarstva. Ekonomika i upravlinnia, 2, 100-106. Available at: https://e-u.edu.ua/journal/ 102.pdf

46. Kanagal, N. B. (2017). Development of Market Orientation for Marketing Strategy Formulation. International Journal of Marketing Studies, 9 (4), 54. doi: https://doi.org/10.5539/ijms.v9n4p54

47. Bustamante, A., Sebastia, L., Onaindia, E. (2020). BITOUR: A Business Intelligence Platform for Tourism Analysis. ISPRS International Journal of Geo-Information, 9 (11), 671. doi: https://doi.org/10.3390/ijgi9110671

48. Kompanets, K. A., Lytvyshko, L. O., Vysochilo, O. N. (2018). Organizational and economic protection of strategic marketing at the enterprise. Visnyk Odeskoho natsionalnoho universytetu. Seriya: Ekonomika, 23 (2 (67)), 56-59.

49. Ritonga, H. M., Setiawan, N., Fikr, M. E., Pramono, C., Ritonga, M., Hakim, T. et. al. (2018). Rural tourism marketing strategy and SWOT analysis: a case study of bandar pasir mandoge sub-district in north sumatera. International Journal of Civil Engineering and Technology, 9 (9), 1617-1631. Available at: https://iaeme.com/MasterAdmin/Journal_uploads/IJCIET/VOLUME_9_ISSUE_9/ IJCIET_09_09_156.pdf 
50. Suharto, R. B., Roy, J., Darma, D. C. (2019). Degree of potential and development strategy of tourism objects. International Journal of Scientific \& Technology Research, 8 (09), 2343-2347. Available at: http://www.ijstr.org/final-print/sep2019/Degree-OfPotential-And-Development-Strategy-Of-Tourism-Objects.pdf

51. Kuklina, T. S. (2011). Udoskonalennia kompleksu marketynhu v zabezpechenni rozvytku turystychnykh pidpryiemstv. Biznesnavihator, 3, 29-33.

52. Barros, C., Sousa, B. (2019). Price and marketing strategy in tourism contexts: a preliminary study to mitigating seasonality. International journal of marketing, communication and new media,7 (12), 24-38.

53. Syamsuddin Amin, M. A., Priansah, P. (2019). Marketing communication strategy to improve tourism potential. Budapest International Research and Critics Institute (BIRCI-Journal): Humanities and Social Sciences, 2 (4), 160-166. doi: https:// doi.org/10.33258/birci.v2i4.575

54. Vinerean, S. (2017). Content marketing strategy. Definition, objectives and tactics. Expert journal of marketing, 5 (2), 92-98.

55. Stankov, U., Gretzel, U. (2020). Tourism 4.0 technologies and tourist experiences: a human-centered design perspective. Information Technology \& Tourism, 22 (3), 477-488. doi: https://doi.org/10.1007/s40558-020-00186-y

56. Pahlevi, A. S., Sayono, J., Hermanto, Y. A. L. (2021). Design of a Virtual Tour as a Solution for Promoting the Tourism Sector in the Pandemic Period. KnE Social Sciences, 368-374. doi: https://doi.org/10.18502/kss.v5i6.9226 